University of New Hampshire

University of New Hampshire Scholars' Repository

\title{
Engagement in a Public Forum: Knowledge, Action, and Cosmopolitanism
}

Jennifer F. Brewer

The University of New Hampshire, jennifer.brewer@unh.edu

Natalie Springuel

Maine Sea Grant

James Wilson

University of Maine

Robin Alden

Maine Center for Coastal Fisheries

Dana Morse

Maine Sea Grant

Follow this and additional works at: https://scholars.unh.edu/geog_facpub

Part of the Civic and Community Engagement Commons, Environmental Policy Commons, Nature and See nextpage for additional authors

Society Relations Commons, Place and Environment Commons, Political Theory Commons, and the

Theory, Knowledge and Science Commons

\section{Comments}

This is an article published by Wiley in Antipode in 2016, available online: https://doi.org/10.1111/anti.12270

\section{Recommended Citation}

Brewer, J.F., N. Springuel, J. Wilson, R. Alden, D. Morse, C. Schmitt, C. Bartlett, T. Johnson, C. Guenther, and D. Brady. 2017. "Engagement in a Public Forum: Knowledge, Action, and Cosmopolitanism." Antipode, 49(2), 273-293.

This Article is brought to you for free and open access by the Geography at University of New Hampshire Scholars' Repository. It has been accepted for inclusion in Geography Scholarship by an authorized administrator of University of New Hampshire Scholars' Repository. For more information, please contact 
Authors

Jennifer F. Brewer, Natalie Springuel, James Wilson, Robin Alden, Dana Morse, Catherine Schmitt, Chris Bartlett, Teresa Joihnson, Carla Guenther, and Damian Brady 


\title{
Engagement in a Public Forum: Knowledge, Action, and Cosmopolitanism
}

\author{
Jennifer F. Brewer
}

Department of Geography University of New Hampshire

Durham, NH, USA

jennifer.brewer@unh.edu

\section{Natalie Springuel}

Maine Sea Grant, University of Maine Orono, Maine, USA

\section{James Wilson}

School of Marine Sciences, University of Maine Orono, Maine, USA

\section{Robin Alden}

Penobscot East Resource Center

Stonington, Maine, USA

\section{Dana Morse}

Maine Sea Grant, University of Maine Orono, Maine, USA

\section{Catherine Schmitt}

Maine Sea Grant, University of Maine Orono, Maine, USA

\section{Chris Bartlett}

Maine Sea Grant, University of Maine Orono, Maine, USA

\section{Teresa Johnson}

School of Marine Sciences, University of Maine Orono, Maine, USA

\section{Carla Guenther}

Penobscot East Resource Center

Stonington, Maine, USA

\section{Damian Brady}

Maine Sea Grant, University of Maine Orono, Maine, USA 


\begin{abstract}
Facing challenges to the civic purpose of higher education, some scholars and administrators turn to the rhetoric of engagement. Simultaneously, the political philosophy of cosmopolitanism has gained intellectual favor, advocating openness to the lived experiences of distant others. We articulate linkages between these two discourses in an extended case study, finding that a cosmopolitan ethos of engagement in a rural context can improve (1) understanding among people ordinarily separated by spatialized social-ecological differences, (2) prospects for longer term environmental sustainability, and (3) the visionary potential of collaborative inquiry. Despite globalization of food systems and neoliberal shifts in fishery management, an annual fisheries forum facilitates coalitions that overcome dichotomies between technocratic and local knowledge, extending benefits to fishing communities, academia, and public policy. Iterative and loosely structured capacity building expands informally through affective processes of recognition and care, as decentralized leadership supports collective mobilization toward alternate futures.

Resumen: Enfrentando los desafíos de los fines cívicos de la educación superior, algunos académicos y administradores tornan a la retórica de engagement o involucración. Al mismo tiempo, la filosofía política del cosmopolitismo ha ganado reconocimiento, abogando por la apertura hacia las vivencias de los demás. Señalamos los vínculos entre estos dos discursos en un extenso estudio de caso, hallando que una ética cosmopolita de engagement en un contexto rural puede mejorar (1) la comprensión entre personas normalmente separadas por diferencias espaciales y socio-ecológicos, (2) las posibilidades de sostenibilidad medioambiental a largo plazo, y (3) el potencial visionario de la indagación colaborativa. A pesar de la globalización de los sistemas alimentarios y el aumento del neoliberalismo en la gestión de la pesca, un foro anual de pesquerías facilita coaliciones que superan las dicotomías entre el conocimiento tecnocrático y local, lo cual extiende beneficios a las comunidades pesqueras, la academia, y la política pública. Un desarrollo de capacidades iterativo y poco estructurado se expande de manera informal a través de procesos afectivos de reconocimiento y cuidado, mientras el liderazgo descentralizado apoya la movilización colectiva hacia futuros alternativos.
\end{abstract}

Keywords: public geography, environmental governance, Maine Fishermen's Forum, Sea Grant, activism, participatory action research

\title{
Introduction
}

The concepts of globalization and neoliberalism have become established scholarly shorthand. Inadvertently, they can obscure facultative choices about how we conduct our daily lives, and depict the reach of mobile capital, colonialist ideologies, associated deployments of new technologies, and urban-rural hierarchies as inexorable. With the wonders of global communications and transport, most people perceive themselves to be in more frequent contact with people and ideas originating in physically removed locales, compared with the experiences of our ancestors. When we encounter unfamiliar lifeways and beliefs, some may seek refuge in xenophobic fantasies, repressing the advance of knowledge through inquiry. The spatial expansion of human relations invites not only violence and waste, but also cooperation, stewardship, and care. Expanded horizons offer unprecedented potential for coalition building, and new encounters can foment alternate futures. The hard work of collaboration among disparate groups in identifying common goals, establishing shared understanding, and integrating disparate knowledge through the voluntary exchange of physical, emotional, and intellectual labor can produce action plans that are at least visionary, and perhaps emancipatory. 
As scholars navigate this emergent socio-spatial terrain, we may reasonably expect that the carefully constructed analyses we present in publications and classrooms will achieve our desired impacts, but fewer of us devote similar attention to the lasting social legacy of activities that garner less academic glory. For those of us who still muddy our boots, our conduct in field settings is often more visible to audiences who will never visit our classrooms or read our journals. Our strategic support for open inquiry in more public venues may improve prospects for liberatory over oppressive outcomes.

It is therefore significant that external critiques of academic institutions arise simultaneously with the reinvigoration of cosmopolitan theory and broadening interest in publicly engaged scholarship. Despite protracted debates about the future of academia, university faculty, staff, and students are well positioned to act as key players in public processes that can produce the inclusive coalitions needed for visionary social action. We can interface with business, government, and non-profit sectors while remaining more focused on long-term, broadly beneficial public goods than on income streams, electoral cycles, or advocacy campaigns that necessitate shorter time horizons and a narrower range of customers, constituencies, or allies.

In this paper, we sketch out ways in which publicly engaged scholars can help advance an ethic of cosmopolitan inquiry, demonstrated by an extended case study. First, we note the rise of engaged scholarship, which spans a range of ideological, disciplinary, and methodological positions. Second, we outline the revival of cosmopolitanism, including efforts to overcome not only spatialized differences, but also temporal and species differences, with implications for human-environment geography. Third, we offer contextual background about Maine fisheries and describe our methodology. Fourth, we discuss the case of academic involvement in an annual event intended to augment public participation in fishery governance. We document the creation of the public forum, the attenuation of fishery relationships within the context of globalization, examples of how the forum facilitates coalition building across difference, improved prospects for resource conservation, and the quiet role of scholars in associated visioning for alternate futures. Lastly, we offer concluding comments to underscore how engagement can nurture cosmopolitanism, even, or perhaps especially, in rural settings such as Maine fishing villages.

\section{Engagement}

In Anglophone regions and beyond, academia faces profound challenges to its raison d'être as a key provider of public goods (Dowling 2008; Hodges and Dubb 2012; Sheppard 2013). Experiences differ across political borders, and among institutions with different historical foci on research, teaching, or service. In the United Kingdom, the allocation of government funding according to quantitative research productivity assessments has spawned extensive debate and undermined faculty morale (Ball 2012; Gregson et al. 2012; Pain et al. 2011; Rogers et al. 2014). In the United States, research assessment burdens are escalating less centrally, but student evaluations of teaching strongly influence career paths of junior faculty, and tenure and promotion processes often privilege research quantity over quality (Benton and Cashin 2014; Lane 2010). For the last two decades, similar experiences have emerged around the globe, including Australia, New Zealand, continental 
Europe, Canada, South Africa, and beyond (Ball 2012; Brown et al. 2010; Chan and Fisher 2008; Larner and Le Heron 2005; Metcalfe 2010; Ntshoe et al. 2008; Rogers et al. 2014). Conservative politicians and financially beleaguered tuition payers increasingly expect higher learning to demonstrate its private value. Some who routinely deploy skills learned at universities to amass monetary wealth and political power now deny the personal and collective benefits of incisive critique, logical rigor, and broad intellectual exposure (Slaughter and Rhoades 2004).

Geographers, like other scholars, therefore find ourselves called upon to defend centuries of cumulative inquiry, and actively demonstrate the enduring relevance of our labor (Dowling 2008; Fuller 2008; Mitchell 2008; Participatory Geographies Research Group 2012; Sheppard 2013; Valentine 2005). For such purposes, some leaders in higher education policy and administration encourage "community engagement" activities as more broadly visible extensions of our mission (Hodges and Dubb 2012; Kellogg Commission on the Future of State and Land-Grant Universities 2000). A definition of engagement offered by the US Carnegie Foundation for the Advancement of Teaching (2013) and broadly echoed by academic administrators encompasses: "collaboration between institutions of higher education and their larger communities (local, regional/state, national, global) for the mutually beneficial exchange of knowledge and resources in a context of partnership and reciprocity". If this definition is not sufficiently vague about the nature or extent of "communities", "benefits", and other key elements, the British Research Excellence Framework 2014 (2012:6) mandates that a portion of federal funding be allocated to institutions producing "excellent research" with "reach and significance ... [that] impacts on the economy, society and/or culture", considering also the institutions' "approach to enabling impact". On the one hand, we might be grateful that these interventions from above are not more prescriptive. On the other hand, even cursory implementation requires innumerable choices, with uncertain ramifications.

Though engaged scholarship is a small portion of the international academic portfolio, it is increasingly prominent in campus publicity, planning, and funder expectations, and has produced a growing body of case studies, lessons learned, and best practices. The most nuanced build on a series of intellectual movements ranging from the 19th century to recent decades, including popular education, agricultural and household management, grassroots social justice activism, and urban revitalization (Brewer 2013c; Greenwood and Levin 1998; Hall 1992; Hodges and Dubb 2012; Kindon et al. 2007; Noffke 1994). Some take a relatively pragmatic approach, seeking to inform or reform existing social structures. Others assert more transformative goals of foundational change in social relations. The most deeply collaborative are often termed participatory action research, with special emphasis on reflexive processes of cooperative agenda setting (Fine 2004; Greenwood and Levin 1998; Kindon et al. 2007; Kitchen 2001; Participatory Geographies Research Group 2012; Reason and Bradbury 2008; Wynne-Jones et al. 2015). Approaches with somewhat different histories include epistemic communities; knowledge co-generation, co-production or co-learning; community-based resource management; citizen science; knowledge-to-action networks; participatory development, research, mapping, or assessment; activist or public scholarship; militant research; and analytic deliberation (Brown and Kyttä 2014; Castleden 
et al. 2012; Fortmann 2009; Fuller 2008; Kumar and Chambers 2003; National Research Council 2009; Russell 2015).

Presented with this diversity of overlapping and divergent practices, we might best understand these as ethical or epistemological positions, rather than specified tools or techniques (Cahill et al. 2015; Fine 2004). Indeed, most engaged researchers acknowledge associated limitations and tradeoffs. Among them, some administrators may be more interested in the public appearance and rhetoric of engagement than with prospects to advance social justice (Gregson et al. 2012; Hodges and Dubb 2012; mrs kinpaisby 2008; Pain et al. 2011; Rogers et al. 2014). Engagement can encourage personal or localized change but fail to precipitate larger-scale transformation (Cameron and Gibson 2005; Kindon et al. 2007). Powerful interests can obstruct policy alternatives (Blackstock et al. 2015). Idealized notions of partner equity, empowerment, and community can become obfuscatory or otherwise problematic (Cooke and Kothari 2001; Kapoor 2005; Kesby 2007). Cultivation of deep trust, identification of shared goals, and efficient negotiation of divergent perspectives can require intensive labor in the establishment and maintenance of long-term relationships (Bacon et al. 2013; Fuller and Askins 2007; Mason 2013; mrs kinpaisby 2008; National Research Council 2009; Pickerill 2014). Academic tenure and promotion committees may not recognize the value of these investments, or find value in products other than peerreviewed publications in select journals (Ball 2012; Castleden et al. 2012; Pickerill 2014; Valentine 2005). Effective policy analysis, community organizing, or advocacy may in fact bear little resemblance to scholarship (Pickerill 2014; Rogers et al. 2014). If scholars adhere to participatory strictures and partner agendas uncritically, loyalties to non-academic partners can even stifle the development or release of scholarly analyses (Castleden et al. 2012; Kesby 2007; Mason et al. 2014; Pickerill 2008). Unlike researcher-controlled laboratory experiments or theoretically bounded observation, solutions for real world problems often require cross-disciplinary solutions. This can create both challenges and opportunities for researchers, who must make strategic choices about how far they stray from their existing expertise (Bacon et al. 2013; Cahill 2007). In turn, non-academic partners incur risks of unrewarded investments, misrepresentation, betrayal of trust, and unexpected results (Cameron and Gibson 2005; Fortmann 2009; Kindon et al. 2007).

On the other hand, benefits of engagement from an academic perspective can include more informed and socially useful research questions, more accurate and thorough data collection, epistemological depth, broader dissemination of results, higher probability of research application and action, and lower transaction costs in pursuant engagement efforts (Bacon et al. 2013; Balazs and Morello-Frosch 2013; Batterbury 2015; Fortmann 2009; Kindon et al. 2007; National Research Council 2009). Benefits to non-academic partners can include useful information, analytical depth, new contacts and allies, publicity, expanded resource access, and greater internal capacity for future knowledge building, community organizing, and communications (Fortmann 2009; Garzón et al. 2013; Kindon et al. 2007; McGuirk and O’Neill 2012; National Research Council 2009; Young and Gilmore 2012). Tradeoffs are inevitable, as no single project can maximize all potential benefits and minimize all possible risks (Kesby 2007; Rogers et al. 2014; Valentine 2005). In reality, engagement exists on a continuum, with varied methods, products, commitments to transformation, definitions of community, 
involvement by academic administrators, and scientific rigor (Brown and Kyttä 2014; Cameron 2007; Castleden et al. 2012; Chatterton 2010; Fuller and Askins 2010; Kindon et al. 2007; Mitchell 2008). To inform such choices, and grasp the breadth of ethical implications, we find it useful to visit an ancient tradition in political philosophy, one presently enjoying a revival.

\section{Cosmopolitanism}

In recent decades, humanists and social scientists across disciplines have advocated, critiqued, and modified theories of cosmopolitanism. Origins trace to the Greek Cynic Diogenes Laërtius who considered himself a citizen of the cosmos (kosmopolitês), and Stoics who wished citizens to consider moral obligations beyond the family and citystate (Nussbaum 2002). Kant and other 18th century thinkers, though often hobbled by colonialist hypocrisy, rekindled philosophical interest in moral responsibilities toward strangers, and potential implementation through legal-political frameworks, especially to avoid armed conflict (Bohman and Lutz-Bachmann 1997). Contemporary cosmopolitanism encompasses multiple strains (Benhabib et al. 2006; Harvey 2009; Mitchell 2007; Skrbiš and Woodward 2013). Some advocate moderate shifts in status quo political orders, while others envision radical change. Some posit ideal models of interpersonal interaction, while others call for collective political mobilizations. Most endorse polycentric institutional arrangements, but some emphasize the need for more powerful social organization at the international scale (Beck and Grande 2010; Held 2010), others pragmatically assert central roles for conventional nation-states (Kant 2006; Kendall et al. 2009; Nussbaum 2002), and yet others focus on social movements and various collectivities that may be extra-, sub-, or supra-national (Benhabib et al. 2006; Sánchez-Flores 2010). Critics note that cosmopolitan theory can be long on admirable ideals but shorter on proposals for practical implementation (Harvey 2009). Some find that the liberatory rhetoric of cosmopolitanism can be confused, intentionally or accidentally, with neoliberal or otherwise reactionary agendas when it asserts the universality of a particular ethical norm rather than recognizing its specificity to a place, time, and social group (Benhabib et al. 2006; Gramsci 1985; Harvey 2009; Jazeel 2011; Sánchez-Flores 2010).

Regardless, cosmopolitanism entails the crossing of boundaries and scales, and thus advances an inherently geographic viewpoint. Sociologist Gerard Delanty (2006:27) sees its utility to critical social theory in moments "wherever new relations between self, other and world develop in moments of openness". Similarly, an extensive literature review by Skrbiš and Woodward (2013:14) underscores the centrality of "openness ... to new experiences, people, places and ideas" as cosmopolitan individuals "enjoy the play of otherness upon oneself". Among geographers, Barney Warf (2012:272) finds that cosmopolitanism "seeks to uncouple ethics from distance, arguing that each person is bound up with, and obligated to, humanity as a whole", thereby inducing "a scalar shift in identity formation" (2012:v). Jeff Popke (2007) points out that cosmopolitanism invites an appreciation for the relational nature of space. Gidwani and Sivaramakrishnan (2003) find cosmopolitanism at various scales, where people produce "newly salient spaces", including rural ones. Katharyne 
Mitchell (2007:710) notes that the "seeds of revolution" are sown when "a sense of care and vulnerability is articulated" at intimate scales of cosmopolitan practice.

Potentially advancing the credibility of a rural cosmopolitanism, political theorist Mónica Judith Sánchez-Flores (2010) proposes that cosmopolitanism should not only increase our compassion toward unknown persons who are distant in space or social standing, but also toward children and non-human nature. She points out that biological research still struggles to understand the organism-environment interactions that shape evolution, and proposes that we replace the diachronic, sequential, and unilinear notion of time prevalent in Western liberalism with a synchronic notion of simultaneity, thereby recognizing a diversity of possible outcomes. She reminds us that raising children in an atmosphere of trust and well-being increases their lifelong capacity to replicate compassion and openness (Sánchez-Flores 2010). Similarly, in a widely cited essay, philosopher Martha Nussbaum (2002) argues for cosmopolitan innovation in education, particularly civics, ecology, and geography. With these broader cosmopolitan visions extending morality to future peoples and their socialecological environments, cosmopolitanism reveals itself as geographic not only in the terms of our society-space subdisciplinary tradition but also our human-environment one. The cosmopolitan position that we are responsible for others bears direct relevance to decisions about the stewardship of natural resources.

To wit, our case study demonstrates that a cosmopolitan ethos of engagement in a rural context can improve understanding among people ordinarily separated by spatialized social-ecological differences, prospects for longer term environmental sustainability, and the visionary potential of collaborative inquiry.

\section{Knowledge to Action}

To demonstrate these linkages, we consider the origins and evolution of the Maine Fishermen's ${ }^{1}$ Forum, an annual event providing public venues for discussion of science and policy issues central to the survival of fishing-reliant families, business, and coastal communities in the northeastern US. Combining the experience of the authors, we have spent more than two centuries in fishing-related work, mostly in Maine, but also in nine other US states, Washington DC, and six other countries. Among us, we have close familiarity with more than 50 engaged research projects at least one year in duration, and hundreds of engaged projects, courses, policy initiatives, pilots, workshops, or other collaborations lasting less than one year. Our most immediate datasets include participant observation and audio-recorded interviews. Two or more authors attended each of the 40 annual meetings of the Fishermen's Forum, and the lead author took field notes at 11 Forums between 1999 and 2016. Five authors collected audio data at or about the Forum in 2015, including 28 audio-recorded interviews with key informants ranging from two minutes to an hour in length. Others contributed to development of the sampling frame or interview questions. Most recordings were initially organized into themes and excerpted to produce a Sea Grant-funded program broadcast on a communityowned radio station (Springuel 2015). The lead author then transcribed and coded 23 pages of selected radio program and interview data and produced a second iteration of themes, deriving all quoted material below from these transcripts. 
Most of our authors have been involved with, or are current staff of, Maine Sea Grant. This is one of 33 university-based extension, research, and education programs located in US coastal states and funded by the US National Oceanic and Atmospheric Administration (NOAA), the federal agency tasked with managing marine, Great Lakes, and coastal resources. Congress modeled Sea Grant after the US land grant agricultural extension system in 1966, based on a proposal advanced by marine scientists, and riding national optimism about the ability of science to enhance economic development. Staff serve boundary spanning roles between science and policy, always maintaining ostensibly neutral positions as convenors, facilitators, communicators, and educators. Others among us have been involved in policy development and advocacy as government and non-profit organization staff.

\section{Case Context}

The state of Maine is adjacent to eastern Canada, with an area of about $92,000 \mathrm{~km}^{2}$. While its population of 1.3 million is growing, for two centuries the rate of growth has been lower than the national average. Its population density ranks at the top of the bottom quartile nationally, with 16.6 people per $\mathrm{km}^{2}$. More densely populated southern counties are only an hour or so from Boston, the nearest metropolitan population greater than one million. More rural northern and eastern counties are up to seven hours from Boston, only slighter farther from Montreal, and closer to Quebec. Among US states, Maine residents are the oldest and least racially diverse. Its balance of jurisdictional power has historically tilted toward localities, with a strong home rule law and with $90 \%$ of municipalities still holding annual town meetings founded on a 17th century legacy of direct democracy.

Although the state's economy is now predominantly service oriented, its cultural identity retains strong ties to natural resource-dependent industries of farming, forestry, and fishing, and the craftsmanship of small-scale manufacturing. About 8000 residents hold commercial fishing licenses, and several thousand more work as unlicensed crew. The vast majority of Maine fishing boats are smaller than 14 meters in length and are owner operated, with only one or two additional crew members. The dockside value of the state's commercial marine resource harvests exceeded US $\$ 600$ million in 2015 , though that figure fluctuates annually with markets and species populations. Target species were highly diversified until the present century, but the vast majority of Maine harvesters now focus their efforts on lobster, with fewer targeting clams, scallops, herring, crabs, eels, worms, and other species. Tuna, shrimp and urchins were lucrative harvests in the past, but are now scarce. Harvests of groundfish ${ }^{2}$ species are now extremely limited because they can include cod, which is severely depleted and thus heavily regulated. For most species, in most years, fishing success relies on close and prolonged observation of species behavior and associated ecological cycles. These phenomena can be highly localized, since the behavior of target species depends on multi-scalar interactions between ocean currents, bathymetric features, and riparian inputs, and corresponding behaviors of predator, prey, and competitor species. Different areas of the coast are radically different, ranging from flat, sandy benthos in the south, to dramatically contoured 
rocky benthos in the east, with patchy variations along the intervening peninsulas. This biophysical complexity makes local knowledge valuable and fishermen therefore share their most precious fishing-related information with only a few close family members or friends (Brewer 2014a; Wilson et al. 2013).

\section{Convening the Forum}

In the early 1970s, two people met on a wharf at the end of a rural peninsula in eastern Maine, both awaiting passage on an island mailboat. Jim Wilson was an Assistant Professor at the flagship, land grant campus of the University of Maine. He had prior experience as a US Peace Corps volunteer and an economics degree from a midwestern land grant university with one of the longest-standing extension traditions. Robin Alden had suspended undergraduate studies at Yale, worked as a local newspaper reporter, then co-launched a state-wide fishing industry newspaper to address the gap between fishermen's knowledge and that of science and regulators.

Robin interviewed Jim for her paper and Jim subsequently recruited Robin to conduct field interviews on research projects funded by NOAA and Maine Sea Grant. The research involved local-level fishing industry networks and a nascent international policy initiative to limit commercial fishing licenses for the purposes of fishery conservation and economic capture of associated rents. At that time, the US and other coastal nations were poised to claim extended marine territories with the intentions of developing mineral resources, industrializing fisheries through bio-economic management, and protecting military interests (Brewer 2011; Galdorisi and Kaufman 2002). Jim and Robin were aware that Maine's fishing industry was acutely unprepared for an impending deluge of federal fishery regulation, and that emotions would run high. For example, at one island meeting, Jim had been threatened with armed violence for even soliciting opinions on license limits, which could threaten future livelihoods. Federal regulation of groundfishing, one of the most historically lucrative fisheries, had never been enforced, and many fishermen had never heard of NOAA.

A few years prior to the burgeoning of social science literatures on institutions and civil society, the pair developed an unpublished "VFW" theory. They posited that the national Veterans of Foreign Wars (VFW) organization succeeded as a powerful lobbying group because its ubiquitous local halls offered relaxed, social, clubtype environments for veterans and their families, where policy discussion was low key and secondary to recreation, but nonetheless mustered ample political capital across local to federal policy levels. Jim saw the principle in action at a fishing industry meeting a few hours south, sponsored by Rhode Island Sea Grant.

With these inspirations, Jim and Robin recruited a few supporters and organized the first Maine Fishermen's Forum to share their recent research findings in a series of panels and discussions with fishery managers, elected officials, scientists, extension staff, and fishing industry members. They located the meeting at a recently built resort hotel with discounted off-season overnight rates, adjacent to a widely known fishing port. Following this initial success, Sea Grant continued to host the meeting with Robin on staff until she returned to her newspaper. The Forum organizing group recognized that a less academic structure would be more productive, 
and shifted the administration first to the newspaper, then to an independent board representing more than a dozen fishing-related organizations. To ensure financial stability, the board added a wildly popular trade show, and now funds a few seasonal staff members, generally members of fishing families. Forty years later, the Forum attracts roughly 4000 people a year, filling the resort and area hotels for two or three days. It boasts dozens of free seminars, panels, and discussions on emerging fishery issues, more than 100 vendors in the trade show, as well as marine safety and cooking workshops, a reception, two dinners, a dance, and children's activities. A live auction raises tens of thousands of dollars for college scholarships. Advance advertising is minimal as most of the industry knows of the perennial event through personal experience, word of mouth, or media coverage.

\section{Attenuated Rural Relationships}

From the beginning, Forum organizers scheduled the event at the cusp of late winter and early spring, when frequent storms make fishing difficult, and Mainers crave any escape from cabin fever. Despite profound changes in socio-spatial relations wrought by globalized food systems, life in rural fishing villages can be isolating. In the 1970s and 1980s, many boys quit high school to live and fish in their home harbors, perhaps leaving the county once or twice a year, and rarely leaving the state. Marine biophysical cycles dominated the daily and seasonal schedules of most coastal villagers, successful boat captains enjoyed social status, and their household members contributed paid or unpaid labor. Because of Maine's irregular coastline, an overland visit to a harbor visible across the water on a nearby peninsula could take more than an hour each way. Since then, improved public schools and social services, cheaper long distance phone service and air travel, inmigration and seasonal residents from out of state, service industry jobs for wives and neighbors, internationalized seafood markets, and the internet have expanded fishing industry horizons, and changed lifestyle expectations. In the 1980s, groundfishing profits soared with federal investment and growing markets. Heavy net trawls came into wide use, requiring larger boats and more crew. These could withstand stormy weather to spend several days at sea, filling large holds. Enterprising fishermen came to know others up and down the coast, as they occasionally visited other harbors to sell catch, buy or repair gear, or pick up crew, and as semi-public marine radio channels were the only available medium for business and personal communications at sea.

Now, groundfishing has largely vanished from Maine due to globalized seafood markets, climate change, and failed federal policy, with most other fisheries also in decline (Brewer 2013b). Lobster trapping has become the most reliable industry refuge, though warming waters pose serious risk of lobster disease and population collapse. As a result, the vast majority of fishermen work in pairs or threesomes on small day boats. They rarely interact with strangers on the water, since harborbased lobstering groups claim and defend local marine spaces (Brewer 2012a; Wilson et al. 2013). Cell phones have moved many communications from radios to private lines. The oral transmission of knowledge about marine navigation and fishing grounds has been partially replaced by sonar depth-finders and Global 
Positioning Systems (Brewer 2012a). Fiberglass boats, mass-produced wire traps, and new engine technologies have replaced local barter exchange with a few large manufacturers. Fishermen are up well before dawn, work long hours in good weather, and have time to socialize in winter. By contrast, family and neighbors are more likely to work year-round office hours or the later hours of the summer hospitality industry, or move southward to more urban areas.

Regulatory changes since the 1970s now divide fishermen from one another in key respects. Management focuses on individual species, with limited predictive capacity of species assessments, and minimal attention to interspecies, or species-habitat relationships. Most federally managed fisheries now limit permits to those fishermen who recorded some minimum volume of landings in specified qualifying years, or require limited permits to be purchased on relatively unregulated markets, some selling for millions of dollars. By contrast, the state lobster fishery still allows young people to enter the fishery if they establish themselves as teenagers (Brewer 2012a). Over time, the costs of boats, fuel, labor, and shoreside access have risen. Given such uncertain returns on investment, it is difficult for young people or career changers to begin fishing, or for fishermen who once targeted multiple species to continue shifting effort. Partly for these reasons, the fishing industry has become older, more specialized, and less optimistic about the future of fishing. Inversely, as a few fisheries such as lobster and eels reap record profits, newer fishermen with no memory of larger catches and lower costs express perilous optimism. Neighbors and family members who previously shared common business interests find themselves factionalized over management issues, struggling to balance short-term personal profits with long-term industry sustainability (Brewer 2013b).

\section{Doing "That Human Thing"}

Many fishermen fear public speaking and the interpersonal negotiations of shoreside life. They become frustrated at the inscrutability of statistical fish population models that drive regulatory decisions, and deeply angry that technocratic regulatory procedure belies cherished notions of participatory democracy (Brewer 2013a). As a result, public hearings organized by fishery management agencies can devolve into adrenalin-riddled exercises in dysfunctional governance, shutting down possibilities for compromise or innovation. In stark contrast, the Fishermen's Forum offers a venue that is participatory, open, and accepting. One fisherman who has led a fishing industry group called the Forum "a neutral setting. There's no stress about it, you can just come. It's not a public hearing." Most scheduled sessions are organized by leaders of fishing industry groups, with others organized by NGOs, fishery managers, Sea Grant staff, or scientists. Some are structured as panels, with speakers seated at a front table or standing to display PowerPoint slides, but others are organized with chairs in a circle, offering equal time to all. The first Forum day usually addresses one broad topic in depth, with panels and facilitated break-out sessions that may produce an array of experiential knowledge, science and policy questions, or action items. Scheduled Forum speakers include industry members as well as scientists, public officials, and NGO staff, and most panels allow substantial time for audience questions, discussion, commentary, 
and critique. Participants expect that any scientific, management, or industry position may be vigorously but respectfully challenged. Sessions are rarely designed to produce a consensus or decision; most aim to stimulate discussion and thought, and generate diverse input.

Conversations ebb and flow from scheduled sessions to the crowded resort bar, lounge areas, hallways, and private rooms. A non-profit staff member called it "drinking from the firehose" and noted that compared to the rest of the year, "you might see people drop their agenda". In this way, the Forum provides an essential conduit for the exchange of perspectives about innumerable fishing-related issues, creating a safe space for conversations that might otherwise be stymied by differences in home harbor, boat size, target species, gear, biological knowledge, or career stage. It is a working vacation, where people enjoy the give and take of novel perspectives. They gain insights about new gear, engines, markets, or marine science; identify allies for pending policy debates; meet prospective research collaborators; and trade "yarns" (stories). In one of the early years, someone reportedly swung from a chandelier. The auction coordinator recalls that in the course of friendly (and well lubricated) competition to raise scholarship funds, people have stripped off suspenders or dungarees for the highest bidder. Even resort staff consider these to be their favorite work days of the year.

The Forum helps build a sense of common identity and purpose. One Sea Grant director considered it the organization's most significant contribution to New England fisheries, noting that "[b]efore that, fishermen didn't think of themselves as an industry" (Schmitt 2015). If so, however, this is an industry shaped by a range of priorities. Boat owners find themselves on equitably moderated speaker panels with environmentalists, public officials, and scientists. Their children swim together and share pizza. Among many stories, one is particularly moving. In the 1970s and 1980s, two brothers from eastern Maine had been lobstering offshore from a 44 foot, Maine-built, wooden boat. They would see huge corporate-owned steel groundfish trawlers from the urban port of Portland in southern Maine. In rough weather, these contacts became precious. Whereas the brothers were acutely vulnerable to the pummeling waves, the large boats were safe, and could stay out fishing longer by rotating exhausted crew.

We knew [those captains] ... They were like uncles to us. We were off there in our 44 Stanley, getting the tar beat out of us, and those guys kind of looked out for us. You know, they were always out. But we knew them as voices on the radio. Some of them we never saw face to face. So years later I'm here [at the Forum], talking to ... folks you hadn't seen in a while. And there's this older fella. He came over, he said "Brian Robbins", and I said "yeah", and he said, "Dick Jellison". Well he was ... skipper on those draggers for years. A voice ... in the gale of wind. You thought you were in a mess, but you could talk to Dick on the radio, and even though he was 100 miles away from you, it just made you feel better about [trails off]. And that was Dick! He came over to see me! And here at the Forum! And that was the kind of thing that if it hadn't been for this, it wouldn't have happened.

An unspoken irony is that because they piloted dramatically different fishing operations, these two captains would be expected to voice opposing positions on 
a range of fishery management issues, ones that could eventually make or break either of their operations (Brewer 2013b, 2014b; Wilson et al. 2013). For all those years, each remembered a more important relationship founded on mortal fear so vivid it remained unnamed even decades later. As Robin explained, such conversations at the Forum open minds:

Often those other people, and those other points of view, are abstractions. You hear them, you read them in the paper ... At the Forum, all of a sudden that person is another human being. They may have their kids in tow. They may be sitting at the bar with you. And so you start to do that human thing of learning that this is another person who for some reason has this outrageous idea that you disagree with, and you start this process of learning to understand each other.

When people expose unexpected vulnerabilities to one another, they open possibilities for recognition, compassion and care. The result can be new appreciation for policy positions once perceived as intolerable. This imbrication of civic deliberation with affect becomes a leverage point for coalition-building. Alliances forged in emotional honesty can advance powerful political messages.

\section{Scholarship and Visioning}

The Forum has also helped shift the course of fisheries knowledge, and assumptions about its production. It is not the only effort aiding new relationships across scientists and harvesters, but it is one that has become a touchstone. As in many areas of natural resource governance, many thoughtful and experienced observers of fisheries management believe that solutions to challenging problems require closer information sharing between harvesters and scientists (Bavinck et al. 2013). Biologists initially attended skeptically, dismissing first-hand observations of fishermen as unimportant or false. While some social scientists already conduct fieldwork in ways that invite fishing industry input, natural scientists are historically trained to dismiss non-academic viewpoints as "anecdotal". Through Forum interactions, many have found that while scientific and fishing observations differ in spatial scale, they can be mutually informative. They thus caveat presentations about "our evidence" or "findings in this study" rather than presuming some monopoly on truth. They enable critique by answering questions about their methodologies and assumptions in accessible language. Despite having no familiarity with social science concepts of reflexivity, they become more aware that even the most ostensibly quantifiable information is a product of its material and social context. Scientists and students now come from more than a dozen colleges and research organizations, one scientist calling it "the single best place to network with the fishing industry". Likewise, fishermen have become more curious about research, and more respectful of ecological limits. As a scalloper said:

It's interesting to see how reproduction and all that stuff actually works, which is something I never really even considered that much. I see what comes up on deck, and I think I know what goes on, but I don't actually know that much about the reproduction of the different species ... It helps you plan your fishery to make it sustainable in the future. 
While most organized advocacy groups concerned with either the business or conservation aspects of fishery management seek fairly pragmatic policy goals, the Forum has also supported more transformative efforts. A fundamental struggle in fisheries policy is to balance personal versus shared interests, and shorter and longer term decision horizons. The Forum makes collective, long-term visioning more feasible, and has facilitated numerous projects, programs, and organizations with this purpose. Partly by providing more fluid, imaginative discourse than any governmental meeting, and a more diverse audience than any blowy day fish house gripe session, the annual event hastens conversations that might otherwise stall in impasse or entropy. At the Forum, plans evolved to establish a seafood display auction as a public-private partnership, transforming the region's finfish markets by raising product quality, increasing profits, and attracting processing plants (Brewer 2014a; Kaplan 2000). Shrimpers embraced gear modifications and repeatedly rejected entry limits, thereby prioritizing equity of access. Lobsterfishermen collaborated with legislators and scientists to decentralize state management with voting mechanisms for gear restrictions and entry limits, and have slowed fishery consolidation (Brewer 2012b). Scallopers reversed a species decline and also established a decentralized co-management mechanism in cooperation with state managers and Robin's non-profit organization. Clammers overcame a legacy of marginalization to convene now-annual state-wide meetings at the Forum and expand innovative experiments in conservation and management. Despite a relatively short history plagued by gold-rush profits and belated regulatory controls, the elver (juvenile eel) fishery countered the prospect of statewide closure by meeting at the Forum to develop communication networks and regulatory options. Groundfishermen have repeatedly called for alternative governance structures to prevent capitalized firms from extinguishing the local spawning populations that can support owner-operators (Brewer 2013b). Although the number of women on fishing boats has increased only slowly, many women have taken on roles of leadership and authority at the Forum. On the other hand, laborers at seafood processing plants and fishing crew have made minimal headway at the Forum, and in fisheries management generally.

The most notable of these efforts also required innumerable conversations in many other venues and may not have begun at the Forum, but compared with other arenas, the Forum attracts a broader range of potential supporters and critics, where new ideas can be generated more collectively, explored more iteratively, and tested more rigorously, with a stronger sense of possibility and momentum. With a diversified ${ }^{3}$ and inquisitive audience, it becomes difficult to dismiss any proposal as too radical, visionary, timid, or unrealistic. Although state agency staff did not attend the first Forum, they now appreciate the opportunity for mutually informative and broad-ranging exchange. As one said: "We think all year long about what topics would be the best to roll out at the Forum-what opportunity this presents to get a dialogue going".

\section{Institutionalizing Openness}

The Fishermen's Forum is an unusually long and loosely structured collaboration between scholars and non-scholars. These roles have evolved over time through multiple iterations of trial and error, informed more by experience than any formal 
guidelines for academic-community partnerships. Key successes have been incremental, guided by longer-term vision, but always adaptive. The university passed along the organizational responsibilities because faculty and administrators realized their own expertise could not respond sufficiently to constant shifts in marine policy and seafood markets. The Forum took on a life of its own as Robin eventually passed on her roles with the Forum and newspaper, was appointed state Commissioner of Marine Resources, then became founder-director of a non-profit organization that facilitates the sharing of management responsibility between natural resource users and government in co-management. Jim recently retired from the university, having earned an international reputation for his research on environmental governance, and an abundance of prestigious publications and grants.

A surprising number of people have attended every one of the 40 Forums, and it feels like old home week to many more. This longevity provides a strong sense of continuity, where past experience is not a historical relic, but a source of learning for evolving livelihoods. It is not a bilateral university-community relationship, but a polycentric network, with academic organizations among its many nodes, alongside non-profit groups of various stripes, businesses of all sizes, and multiple levels of government (Brewer 2013c). Unlike "stakeholders" at regulatory hearings, people are expected to speak for themselves, not for their employers. Most researchers do not conduct formalized data collection at the Forum, but use the venue for relationship building, absorbing perspectives that can stimulate new research questions or reframe data interpretation. This is not one-stop shopping, but a personal-professional investment with uncertain payoffs. It is a time for listening and probing, opening boxes rather than closing them. Many non-scholars use the occasion to familiarize themselves with individual scientists and research areas, making decisions about if and how to engage in the future. When NOAA offers funding for fishery-collaborative research, the Forum is a leading place for the exploration of shared interests, and discussion of project findings. Although some business and advocacy groups use the venue to posture on polarized issues, and some government staff use it to demonstrate their responsiveness to constituents, the prevalence of surprise challenges such discursive positions and many attendees instead use the time to reconnect their professional missions and personal values, a bit like a vocational retreat.

Despite this lack of agreed-upon structure in scholar-community relations, or perhaps because of it, the Forum provides a diversified flow of information that can inform the flourishing and growth of other engagements. It is now one of numerous long-term involvements that have stimulated more formal institutional commitments among faculty and administration. The University of Maine School of Marine Sciences now considers public engagement explicitly in hiring and tenure decisions. They and others on campus have discovered the literature on knowledge-to-action networks, and have leveraged it to obtain increasingly large grants. This is especially significant at a time when the state university system is being targeted by a governor with unprecedented determination to cut public programs and repurpose higher education. On most campuses today, an untenured professor investing the quantities of time jim devoted to engagement would likely encounter difficulties in the tenure process, as quantitative expectations for publications and teaching have risen. At every turn, new faculty must be strategic in producing short-term deliverables with clear documentation in a dossier 
tailored to the anticipated tenure committee. Admittedly, this can improve transparency and accountability in personnel decisions, but by contrast, the most intellectually fascinating ideas emerging from Jim's public engagements, focused around learning and the role of information in environmental governance, increasingly drew him away from the conventions of his home discipline of economics and into high-visibility, crossdisciplinary collaborations with long payoff periods.

The Forum and its continued influence throughout Robin's subsequent career helped establish norms of participatory governance that now extend beyond the state. A series of parallel legal, regulatory, and procedural changes have fostered a state marine policy arena in which marine harvesters expect opportunities for substantive, public discussion, well prior to any regulatory notice-and-comment period (Brewer 2013a; Johnson and Zydlewski 2012). When scholars weigh in on fishery-related issues, the public expects them to do so in a way that is accessible and explanatory, fully deploying our skills as educators and servants as well as researchers. When Jim's students and close colleagues or Robin's current and former staff become involved with groups and processes outside the state, they bring ideas about co-management that NOAA now recognizes as Maine grown. There are other projects and organizations that also promote this orientation, but the Forum reminds fellow travelers that we are not alone in this. Without the annual event, it would be easier to fall into technocratic assumptions that otherwise predominate in marine governance, abandoning commitments to open deliberation and transformative visioning.

\section{Conclusion}

The Maine Fishermen's Forum is driven by an enduring ethos of problem-solving, collaborative inquiry, and capacity building, rather than any particular methodological convention, engaged or otherwise. It blurs scholarly distinctions among research, service, and teaching; technocratic distinctions between the making and use of knowledge; and socio-ecological distinctions between fishing industry subgroups. It overcomes the isolation of rural fishing livelihoods in an era of globalization and neoliberalism, and encourages openness to care and pleasure across difference. Partly due to the foresightedness of early organizers, the gathering supports deliberation across a range of pragmatic and transformative policy positions, and thereby hastens the development of coalitions and long-term visioning.

Industry members take leading roles in determining the event format and topical content, and find themselves repeatedly challenged to consider alternate viewpoints on issues of equity and stewardship. Scholars play key roles, but on equal footing with non-scholars. They are particularly effective when they abandon the postures of academic debate, and adopt decentralized leadership styles that more closely resemble the humble posture of community organizing, quietly supporting the self-education of others. Although some might not embrace the label of activist, they nonetheless promote transformative change, forging clearer ties between scientific and civic knowledges than is possible in classroom lectures or journal articles.

The Forum demonstrates an extension of cosmopolitanism to rural contexts, a recurring moment of hope in the face of globalized and technocratically managed 
food systems. It engenders not only openness to the insights gleaned in conversation with strangers, but normalizes inclinations toward the stewardship of environmental resources for future generations. Over time, it has become an important locus for the building of engaged partnerships across broader non-profit, private, and governmental arenas. Dozens of other fisheries-related groups have since incorporated linked purposes into their missions, but the annual meeting remains an anchor, like a perpetual family reunion, replete with feuds, allegiances, pleasures, and unending opportunities for growth-for individuals and collectivities of colearners. This legacy suggests that a central value of engagement may be in inviting scholars and non-scholars to entertain an array of alternate possible futures, ones enriched by broadened consciousness of publics we might otherwise dismiss. Scholars can support such visioning not only by undertaking formal partnerships, but as interactive participants in informal and robustly egalitarian modes of inquiry, enacting cosmopolitanism as both ethic and practice. Admittedly, we cannot trace direct causality between such efforts and the pace of university budget cuts. But the more diverse publics perceive collective benefits of various scholarly endeavors beyond the classroom, the more we might protect and revitalize our broader civic mission.

\section{Acknowledgements}

We owe sincere thanks to many project partners for their patience and trust, and to colleagues and administrators who appreciate the tensions between conventional and engaged scholarship. Thank you to Jeff Popke for commenting on an early version of this paper, and to anonymous reviewers for their helpful critiques, insights, and suggestions.

\section{Endnotes}

1 It is difficult to avoid the gender-biased term "fisherman" when discussing New England fisheries. Although the number of women who fish is increasing, the overwhelming majority wish to be identified as fishermen. Apparent alternatives include fisher and fisherfolk. In New England, a fisher is a widely detested mammal that frequently kills housecats. Fisherfolk can be useful in the plural, but has no singular form.

2 Groundfish are finfish that live on or near the sea floor.

3 There are limits to the Forum's diversity. Since its inception, women have made great strides as industry organizers, policy professionals, and crew, but fewer have become boat captains. The few brown-skinned crew and seafood-processing workers have never attended the Forum in noticeable numbers. Heteronormativity clearly predominates, but is not universal. Nonetheless, the Forum is the most diversified fishery event in the state in terms of the age, home port, target species, boat size, gear type, capital access, and management priorities of participants.

\section{References}

Bacon C, de Vuono-Powell S, Frampton M L, LoPresti T and Pannu C (2013) Introduction to empowered partnerships: Community-based participatory action research for environmental justice. Environmental Justice 6(1):1-8

Balazs C L and Morello-Frosch R (2013) The three " $r$ "s: How community-based participatory research strengthens the rigor, relevance, and reach of science. Environmental Justice 6(1):9-16 
Ball S J (2012) Performativity, commodification and commitment: An I-Spy guide to the neoliberal university. British Journal of Educational Studies 60(1):17-28

Batterbury S (2015) Doing political ecology inside and outside the academy. In R L Bryant (ed) The International Handbook of Political Ecology (pp 27-43). London: Edward Elgar

Bavinck M, Chuenpagdee R, Jentoft S and Kooiman J (eds) (2013) Governability of Fisheries and Aquaculture: Theory and Applications. Dordrecht: Springer

Beck U and Grande E (2010) Varieties of second modernity: The cosmopolitan turn in social and political theory and research. British Journal of Sociology 61(3):409-443

Benhabib S, Waldron J, Honig B, Kymlicka W and Post R (2006) Another Cosmopolitanism. Oxford: Oxford University Press

Benton S L and Cashin W E (2014) Student ratings of instruction in college and university courses. In M B Paulsen (ed) Higher Education: Handbook of Theory and Research (pp 279-326). Dordrecht: Springer

Blackstock K, Dinnie L, Dilley R, Marshall K, Dunglinson J, Trench H, Harper K, Finan K, MacPherson J, Johnston E and Griffin A (2015) Participatory research to influence participatory governance: Managing relationships with planners. Area 47(3):254-260

Bohman J and Lutz-Bachmann M (eds) (1997) Perpetual Peace: Essays on Kant's Cosmopolitan Ideal. Cambridge: MIT Press

Brewer J F (2011) Paper fish and policy conflict: Catch shares and ecosystem-based management in Maine's groundfishery. Ecology and Society 16(1). http://www.ecologyandsociety. org/vol16/iss1/art15/ (last accessed 7 June 2016)

Brewer J F (2012a) Don't fence me in: Boundaries, policy, and deliberation in Maine's lobster commons. Annals of the American Association of Geographers 102(2):383-402

Brewer J F (2012b) Revisiting Maine's lobster commons: Rescaling political subjects. International Journal of the Commons 6(2):319-343

Brewer J F (2013a) From personal experience to public participation: Social learning at the community fisheries action roundtable. Environmental Management 52(2):321-334

Brewer J F (2013b) Making an environmental market, unmaking adaptive capacity: Species commodification in the New England groundfishery. Geoforum 50:172-181

Brewer J F (2013c) Toward a publicly engaged geography: Polycentric and iterated research. Southeastern Geographer 53(3):328-347

Brewer J F (2014a) Harvesting a knowledge commons: Collective action, transparency, and innovation at the Portland Fish Exchange. International Journal of the Commons 8(1):155-178

Brewer J F (2014b) Hog Daddy and the walls of steel: Catch shares and ecosystem change in the New England groundfishery. Society and Natural Resources 27(7):724-741

Brown T, Goodman J and Yasukawa K (2010) Academic casualization in Australia: Class divisions in the university. Journal of Industrial Relations 52(2):169-182

Brown G and Kyttä M (2014) Key issues and research priorities for public participation GIS (PPGIS): A synthesis based on empirical research. Applied Geography 46:122-136

Cahill C (2007) The personal is political: Developing new subjectivities through participatory action research. Gender, Place and Culture 14(3):267-292

Cahill C, Sultana F and Pain R (2015) Participatory ethics: Politics, practices, institutions. ACME 6(3):304-318

Cameron J (2007) Linking participatory action to research: Institutional challenges. In S Kindon, R Pain and M Kesby (eds) Participatory Action Research Approaches and Methods: Connecting People, Participation, and Place (pp 206-215). London: Routledge

Cameron J and Gibson K (2005) Participatory action research in a poststructuralist vein. Geoforum 36(3):315-331

Carnegie Foundation for the Advancement of Teaching (2013) Community Engagement Elective Classification. Stanford: Carnegie Foundation for the Advancement of Teaching. http://classifications.carnegiefoundation.org/descriptions/community_engagement.php (last accessed 18 May 2016)

Castleden H, Morgan V S and Lamb C (2012) "I spent the first year drinking tea": Exploring Canadian university researchers' perspectives on community-based participatory research involving Indigenous peoples. Canadian Geographer 56(2):160-179

Chan A and Fisher D (2008) The Exchange University: Corporatization of Academic Culture. Vancouver: UBC Press 
Chatterton P (2010) Autonomy: The struggle for survival, self-management and the common. Antipode 42(4):897-908

Cooke B and Kothari U (eds) (2001) Participation: The New Tyranny? London: Zed

Delanty G (2006) The cosmopolitan imagination: Critical cosmopolitanism and social theory. British Journal of Sociology 57(1):25-47

Dowling R (2008) Geographies of identity: Labouring in the "neoliberal" university. Progress in Human Geography 32(6):812-820

Fine $M$ (2004) Participatory action research: From within and beyond prison bars. In L Weis and M Fine (eds) Working Method: Research and Social Justice (pp 95-119). New York: Routledge

Fortmann L (ed) (2009) Participatory Research in Conservation and Rural Livelihoods: Doing Science Together. Oxford: Wiley-Blackwell

Fuller D (2008) Public geographies: Taking stock. Progress in Human Geography 32(6):834-844

Fuller D and Askins K (2007) The discomforting rise of "public geographies": A "public" conversation. Antipode 39(4):579-601

Fuller D and Askins K (2010) Public geographies II: Being organic. Progress in Human Geography 34(5):654-667

Galdorisi G V and Kaufman A G (2002) Military activities in the exclusive economic zone: Preventing uncertainty and defusing conflict. California Western International Law Journal 32(253):253-301

Garzón C, Beveridge B, Gordon M, Martin C, Matalon E and Moore E (2013) Power, privilege, and the process of community-based participatory research: Critical reflections on forging an empowered partnership for environmental justice in West Oakland, California. Environmental Justice 6(2):71-78

Gidwani V and Sivaramakrishnan K (2003) Circular migration and rural cosmopolitanism in India. Contributions to Indian Sociology 37(1/2):339-367

Gramsci A (1985) Selections From Cultural Writings (eds G Nowell-Smith and D Forgacs). Cambridge: Harvard University Press

Greenwood D J and Levin M (1998) Introduction to Action Research: Social Research for Social Change. Thousand Oaks: Sage

Gregson N, Watkins H, Broughton L, Mackenzie J and Shepherd J (2012) Building bridges through performance and decision-making: Schools, research and public engagement. Antipode 44(2):343-364

Hall B (1992) From margins to center? The development and purpose of participatory research. The American Sociologist 23(4):15-28

Harvey D (2009) Cosmopolitanism and the Geographies of Freedom. New York: Columbia University Press

Held D (2010) Cosmopolitanism: Ideals and Realities. Cambridge: Polity

Hodges R A and Dubb S (2012) The Road Half Traveled: University Engagement at a Crossroads. East Lansing: Michigan State University Press

Jazeel T (2011) Spatializing difference beyond cosmopolitanism: Rethinking planetary futures. Theory, Culture and Society 28(5):75-97

Johnson T and Zydlewski G B (2012) Research for the sustainable development of tidal power in Maine. Maine Policy Review 21(1):58-65

Kant I (2006) Toward Perpetual Peace and Other Writings on Politics, Peace, and History (ed P Kleingeld; trans D L Colclasure. New Haven: Yale University Press

Kaplan I M (2000) Seafood auctions, market equity, and the buying and selling of fish: Lessons on co-management from New England and the Spanish Mediterranean. Marine Policy 24(2):165-177

Kapoor I (2005) Participatory development, complicity, and desire. Third World Quarterly 26 (8):1203-1220

Kellogg Commission on the Future of State and Land-Grant Universities (2000) Renewing the Covenant: Learning, Discovery, and Engagement in a New Age and Different World. Washington, DC: National Association of State Universities and Land-Grant Colleges

Kendall G, Skrbiš Z and Woodward I (2009) The Sociology of Cosmopolitanism: Globalization, Identity, Culture and Government. London: Palgrave

Kesby M (2007) Spatializing participatory approaches: The contribution of geography to a mature debate. Environment and Planning A 39(12):2813-2831 
Kindon S, Pain R and Kesby M (eds) (2007) Participatory Action Research Approaches and Methods: Connecting People, Participation, and Place. London: Routledge

Kitchen R M (2001) Using participatory action research approaches in geographical studies of disability: Some reflections. Disability Studies Quarterly 21(4):61-69

Kumar S and Chambers R (2003) Methods for Community Participation: A Complete Guide for Practitioners. Bradford: Intermediate Technology

Lane J (2010) Let's make science metrics more scientific. Nature 464(7288):488-489

Larner W and Le Heron R (2005) Neoliberalizing spaces and subjectivities: Reinventing New Zealand universities. Organization 12(6):843-862

Mason K (2013) Academics and social movements: Knowing our place, making our space. ACME 12(1):22-43

Mason K, Brown G and Pickerill J (2014) Epistemologies of participation, or, What do critical human geographers know that's of any use? Antipode 45(2):252-255

McGuirk P and O'Neill P (2012) Critical geographies with the state: The problem of social vulnerability and the politics of engaged research. Antipode 44(4):1374-1394

Metcalfe A S (2010) Revisiting academic capitalism in Canada: No longer the exception. Journal of Higher Education 81(4):489-514

Mitchell K (2007) Geographies of identity: The intimate cosmopolitan. Progress in Human Geography 31(5):706-720

Mitchell K (2008) Becoming political. Antipode 40(3):345-350

mrs kinpaisby (2008) Taking stock of participatory geographies: Envisioning the communiversity. Transactions of the Institute of British Geographers 33(3):292-299

National Research Council (2009) Informing Decisions in a Changing Climate. Washington, DC: National Academies Press

Noffke S (1994) Action research: Towards the next generation. Educational Action Research 2 (1):9-21

Ntshoe I, Higgs P, Higgs L G and Wolhuter C C (2008) The changing academic profession in higher education and new managerialism and corporatism in South Africa. South African Journal of Higher Education 22(2):391-403

Nussbaum M C (2002) Patriotism and cosmopolitanism. In M C Nussbaum and J Cohen (eds) For Love of Country? (pp 3-17). Boston: Beacon

Pain R, Kesby M and Askins K (2011) Geographies of impact: Power, participation, and potential. Area 43(2):183-188

Participatory Geographies Research Group (2012) Connectivity, creativity, hope, and fuller subjectivities: Appreciating the responses to the "Communifesto For Fuller Geographies". AntipodeFoundation.org 17 December. https://antipodefoundation.org/2012/12/17/ symposium-on-pygyrgs-communifesto-for-fuller-geographies-authors-reply-to-criticalresponses/ (last accessed 8 June 2016)

Pickerill J (2008) The surprising sense of hope. Antipode 40(3):482-487

Pickerill J (2014) The timeliness of impact: Impacting who, when, and for whose gain? ACME 13(1):24-26

Popke J (2007) Geography and ethics: Spaces of cosmopolitan responsibility. Progress in Human Geography 31(4):509-518

Reason P and Bradbury H (eds) (2008) Handbook of Action Research ( $2^{\text {nd }}$ edn). Thousand Oaks: Sage

Research Excellence Framework 2014 (2012) Panel Criteria and Working Methods. London: Higher Education Funding Council for England. http://www.ref.ac.uk/media/ref/content/ pub/panelcriteriaandworkingmethods/01_12.pdf (last accessed 8 June 2016)

Rogers A, Bear C, Hunt M, Mills S and Sandover R (2014) The impact agenda and human geography in UK higher education. ACME 13(1):1-9

Russell B (2015) Beyond activism/academia: Militant research and the radical climate and climate justice movement(s). Area 47(3):222-229

Sánchez-Flores M J (2010) Cosmopolitan Liberalism: Expanding the Boundaries of the Individual. New York: Palgrave MacMillan

Schmitt C (2015) 40 years of the Maine Fishermen's Forum. Maine Sea Grant blog 4 March. http://www.seagrant.umaine.edu/blog/fishermens-forum (last accessed 8 June 2016) 
Sheppard E (2013) Geography and the neoliberalizing academy. President's Column, AAG Newsletter 31 May. http://news.aag.org/2013/05/geography-and-the-neoliberalizingacademy/ (last accessed 8 June 2016)

Skrbiš Z and Woodward I (2013) Cosmopolitanism. Thousand Oaks: Sage

Slaughter S and Rhoades G (2004) Academic Capitalism and the New Economy: Markets, State, and Higher Education. Baltimore: Johns Hopkins University Press

Springuel N (2015) The Maine Fishermen's Forum: A 40 year retrospective. Coastal Conversations, WERU Community Radio 24 April. http://www.seagrant.umaine.edu/ coastalconversations (last accessed 8 June 2016)

Valentine G (2005) Geography and ethics: Moral geographies? Ethical commitment in research and teaching. Progress in Human Geography 29(4):483-487

Warf B (2012) Cosmopolitanism and space. Geographical Review 102(3):271

Wilson J A, Acheson J M and Johnson T R (2013) The cost of useful knowledge and collective action in three fisheries. Ecological Economics 96:165-172

Wynne-Jones S, North P and Routledge P (2015) Practising participatory geographies: Potentials, problems, and politics. Area 47(3):218-221

Young J C and Gilmore M P (2012) The spatial politics of affect and emotion in participatory GIS. Annals of the Association of American Geographers 103(4):808-823 